\title{
Bioactive Compounds and Antioxidant Activity of Fresh and Processed White Cauliflower
}

\author{
Fouad A. Ahmed and Rehab F. M. Ali \\ Department of Biochemistry, Faculty of Agriculture, Cairo University, Giza 12613, Egypt \\ Correspondence should be addressed to Rehab F. M. Ali; malk_anany@yahoo.com
}

Received 3 March 2013; Revised 13 August 2013; Accepted 17 August 2013

Academic Editor: Elvira Gonzalez De Mejia

Copyright (C) 2013 F. A. Ahmed and R. F. M. Ali. This is an open access article distributed under the Creative Commons Attribution License, which permits unrestricted use, distribution, and reproduction in any medium, provided the original work is properly cited.

\begin{abstract}
Brassica species are very rich in health-promoting phytochemicals, including phenolic compounds, vitamin C, and minerals. The objective of this study was to investigate the effect of different blanching (i.e., water and steam) and cooking (i.e., water boiling, steam boiling, microwaving, and stir-frying) methods on the nutrient components, phytochemical contents (i.e., polyphenols, carotenoids, flavonoid, and ascorbic acid), antioxidant activity measured by DPPH assay, and phenolic profiles of white cauliflower. Results showed that water boiling and water blanching processes had a great effect on the nutrient components and caused significant losses of dry matter, protein, and mineral and phytochemical contents. However, steam treatments (blanching and cooking), stir-frying, and microwaving presented the lowest reductions. Methanolic extract of fresh cauliflower had significantly the highest antioxidant activity (68.91\%) followed by the extracts of steam-blanched, steam-boiled, stir-fried, and microwaved cauliflower $61.83 \%, 59.15 \%, 58.93 \%$, and $58.24 \%$, respectively. HPLC analysis revealed that the predominant phenolics of raw cauliflower were protocatechuic acid (192.45), quercetin (202.4), pyrogallol (18.9), vanillic acid (11.90), coumaric acid (6.94), and kaempferol (25.91) mg/100 g DW, respectively.
\end{abstract}

\section{Introduction}

Plant-based foods such as fruit, vegetables, and whole grains, which contain significant amounts of bioactive phytochemicals, may provide desirable health benefits beyond basic nutrition to reduce the risk of chronic diseases. Epidemiological evidence suggests that consumption of a diet rich in vegetables and fruits has positive implications for human health [1]. In the last decades, special attention has been paid towards edible plants, especially those that are rich in secondary metabolites (frequently called phytochemicals), and nowadays, there is an increasing interest in the antioxidant activity of such phytochemicals present in diet. Recent reports suggest that cruciferous vegetables act as a good source of natural antioxidants due to the high levels of carotenoids, tocopherols, and ascorbic acid, and strong epidemiological evidence shows that these compounds may help to protect the human body against damage by reactive oxygen species. In addition to carotenoids, tocopherols, and ascorbic acid, most of the antioxidative effect related to plant food intake is mainly due to the presence of phenolic compounds, which have been associated with flavour and colour characteristics of fruits and vegetables. In this aspect, the popularity and consumption of vegetable Brassica species is increasing because of their nutritional value. Brassica crops have been related to the reduction of the risk of chronic diseases including cardiovascular diseases and cancer. Brassica foods are very nutritive, providing nutrients and health-promoting phytochemicals such as vitamins, carotenoids, fiber, soluble sugars, minerals, glucosinolates, and phenolic compounds [2]. Vegetables of Brassicaceae family are the essential sources of phenolic compounds in the human diet. They also contain derivatives of hydroxycinnamic, caffeic, chlorogenic, ferulic, and synapic acids as well as flavonols (kaempferol derivatives, and quercetin derivatives) and anthocyanins (red cabbage) $[3,4]$ Brassica vegetables have been reported as good sources of antimutagens. Several epidemiological studies showed that they were associated with reduction of cancer [5]. Further studies of experimental animals also demonstrated that feeding some of these vegetables could inhibit the development of some chemically induced carcinogenesis [6] and resulted in the induction of phase 2 detoxifying enzymes 
such as glutathione S-transferase. It has been reported that natural compounds in these vegetables were effective in protection against chemical carcinogenesis by modulating carcinogen metabolism [7]. Cauliflower, like broccoli and cabbage, belongs to the cruciferous (Brassicaceae) family of vegetables, which has been shown to be effective in fighting certain forms of cancer. Cauliflower is so closely related to broccoli that both are designated as the same variety of the cruciferous family, which not only share the wonderful phytochemicals, but also contain nutritive value of vitamin A, thiamine, riboflavin, niacin, vitamin $\mathrm{C}$, calcium, iron, phosphorous, and fat to help fight diseases [8]. Cauliflower is an important vegetable grown all over the world and has a wide variety of uses directly as a vegetable or as an ingredient in salads, soups, and so forth. Cauliflower occupies an area of 8.88 million ha, having a production of 16.40 million tons in the world [9]. The aim of the current investigation was to determine the effect of different blanching and cooking methods on the nutritional quality of white cauliflower by assessing the proximate composition, the count of total polyphenols, total flavonoids, total carotenoids and vitamin $\mathrm{C}$, and fractionation of phenolic compounds using HPLC as well as antioxidant activity by DPPH of raw and processed cauliflower.

\section{Material and Methods}

2.1. Cauliflower. Freshly harvested cauliflowers (Brassica oleracea var. botrytis L.) were purchased from the local market on the day of processing (Giza Governorate, Egypt) during the winter season (December 2012). Cauliflower heads were selected at marketable stage, free from insect or mechanical damage. Cauliflower heads were transported to the laboratory of biochemistry department, Faculty of Agriculture, Cairo University, Egypt, where the inedible parts were removed using a sharp knife. The cauliflower was cut into almost equal small bite-sized pieces (edible florets, about $5 \mathrm{~cm}$ ), mixed well, and divided into portions (200 g).

\subsection{Pretreatments}

2.2.1. Water Blanching. Approximately $1000 \mathrm{~mL}$ of water was poured into a stainless steel vessel and heated at $100^{\circ} \mathrm{C}$. Cauliflower florets $(200 \mathrm{~g})$ were immersed in the boiling water at $100^{\circ} \mathrm{C}$ for $3 \mathrm{~min}$. The samples were drained on a stainless sieve until cold and then weighed.

2.2.2. Steam Blanching. Steam blanching was conducted by suspending $200 \mathrm{~g}$ of cauliflower florets above $1000 \mathrm{~mL}$ of boiling water for $3 \mathrm{~min}$ in a stainless steel steamer with a lid. The samples were drained on a stainless sieve until cold and then weighed.

2.2.3. Cooking Treatments. The time taken for the completeness of cooking was determined after three initial standardization trials. For all cooking treatments, the minimum cooking time to reach a similar tenderness for an adequate palatability and taste, according to the Egyptian eating habits, was used.
2.2.4. Water Boiling. Approximately $1000 \mathrm{~mL}$ of water was poured into a stainless steel vessel, which was then covered with a lid and heated to boiling. Cauliflower florets $(200 \mathrm{~g})$ were added to the boiling water and cooked for $6 \mathrm{~min}$. The samples were drained on a stainless sieve until cold and then weighed.

2.2.5. Steam Boiling. Steam boiling was conducted by suspending $200 \mathrm{~g}$ of cauliflower florets above $1000 \mathrm{~mL}$ of boiling water for $6 \mathrm{~min} 15 \mathrm{~s}$. in a stainless steel steamer with a lid. The samples were drained on a stainless sieve until cold and then weighed.

2.2.6. Microwave Cooking. A microwave oven (Olympic Electric, Model Kor-1AOA, $2450 \mathrm{MHz}$, Korea) at full power $(1000 \mathrm{~W})$ was used for microwaving. Cauliflower florets $(200 \mathrm{~g})$ were placed in a glass beaker (Type Birex, England), and $10 \mathrm{~mL}$ water was added to prevent cauliflower from being burned during cooking and then cooked in a microwave oven for $3 \mathrm{~min} 30 \mathrm{~s}$. The samples were drained on a stainless sieve until cold and then weighed.

Stir-Frying. Cauliflower florets (200 g) were placed in heated $\left(140 \pm 2^{\circ} \mathrm{C}\right)$ sunflower oil $(10 \mathrm{~mL})$ and stir-fried for $4 \mathrm{~min} 30 \mathrm{~s}$. At the end of each trial, samples were drained off and dabbed with blotting paper to allow for the absorption of exceeding oil.

Fresh and processed samples were kept at $-25^{\circ} \mathrm{C}$ until analysis.

\subsection{Analytical Methods}

2.3.1. Chemical Composition. Moisture, crude oil, crude protein $(N \times 6.25)$, and total ash of samples were determined as described in [10]. The minerals, that is, $\mathrm{Ca}, \mathrm{Fe}, \mathrm{Zn}, \mathrm{K}, \mathrm{Cu}$, $\mathrm{Me}, \mathrm{Mg}$, and $\mathrm{Na}$, were determined in a dilute solution of the ashed samples by atomic absorption spectrophotometer (3300 PerkinElmer) on described in [10]. The results are expressed as dry weight (DW) basis.

2.3.2. Ascorbic Acid Determination. Ascorbic acid content was determined according to [11]. Official Method 985.33 (2, 6-dichloroindophenol titrimetric method). Ascorbic acid content is expressed as $\mathrm{mg} / 100 \mathrm{~g} \mathrm{DW}$.

2.3.3. Total Carotenoids Determination. Total carotenoids were determined according to the procedure given by [12] as follows: $5 \mathrm{~g}$ of cauliflower florets were grinded and extracted with a mixture of acetone and petroleum ether $(1: 1, \mathrm{v} / \mathrm{v})$ repeatedly using the mortar and pestle until a colorless residue was obtained. The upper phase was collected and combined with crude extracts after being washed for several times with water. The extracts were made up to a known volume with petroleum ether. Total carotenoids content was determined by recording the absorbance at $451 \mathrm{~nm}$ with a spectrophotometer. Total carotenoids were estimated by $\mathrm{mg} / 100 \mathrm{~g} \mathrm{DW}$.

2.3.4. Determination of Total Polyphenols. Total phenolics were determined using the Folin-Ciocalteu reagent [13]. 
TABLE 1: Effect of different blanching and cooking methods on the chemical composition of cauliflower florets (g/100 g dry weight basis).

\begin{tabular}{|c|c|c|c|c|c|c|c|c|}
\hline \multirow{2}{*}{ Component } & \multirow{2}{*}{ Raw } & \multicolumn{2}{|c|}{ Blanching } & \multicolumn{2}{|c|}{ Boiling } & \multirow{2}{*}{ Microwave cooking } & \multirow{2}{*}{ Stir-frying } & \multirow{2}{*}{ LSD at 0.05} \\
\hline & & Steam & Water & Steam & Water & & & \\
\hline Moisture & $88.64^{\mathrm{c}} \pm 1.14$ & $90.04^{b c} \pm 2.07$ & $92.62^{\mathrm{a}} \pm 1.10$ & $91.18^{\mathrm{ab}} \pm 2.04$ & $92.97^{\mathrm{a}} \pm 1.65$ & $91.13^{b} \pm 1.20$ & $86.24^{\mathrm{d}} \pm 1.64$ & 1.621 \\
\hline $\begin{array}{l}\text { Crude protein } \\
(N \times 6.25)\end{array}$ & $27.77^{\mathrm{a}} \pm 0.34$ & $26.59^{\mathrm{ab}} \pm 0.85$ & $25.75^{\mathrm{b}} \pm 0.94$ & $26.15^{\mathrm{ab}} \pm 1.06$ & $25.34^{\mathrm{b}} \pm 0.89$ & $26.89^{\mathrm{ab}} \pm 0.17$ & $25.44^{\mathrm{b}} \pm 0.30$ & 1.282 \\
\hline Ether extract & $2.20^{\mathrm{b}} \pm 0.14$ & $2.09^{b c} \pm 0.09$ & $1.93^{c} \pm 0.10$ & $2.04^{\mathrm{bc}} \pm 0.09$ & $1.92^{c} \pm 0.07$ & $2.07^{b c} \pm 0.07$ & $9.72^{\mathrm{a}} \pm 0.10$ & 0.169 \\
\hline Crude fiber & $11.57^{\mathrm{b}} \pm 0.41$ & $11.56^{\mathrm{b}} \pm 0.36$ & $11.52^{\mathrm{b}} \pm 0.54$ & $11.54^{\mathrm{b}} \pm 0.35$ & $12.74^{\mathrm{a}} \pm 0.38$ & $11.54^{\mathrm{b}} \pm 0.62$ & $11.55^{\mathrm{b}} \pm 0.21$ & 0.746 \\
\hline Ash & $11.03^{\mathrm{a}} \pm 0.08$ & $9.72^{\mathrm{ab}} \pm 0.68$ & $9.18^{\mathrm{b}} \pm 0.57$ & $9.60^{\mathrm{ab}} \pm 0.25$ & $7.12^{\mathrm{c}} \pm 0.30$ & $9.65^{\mathrm{ab}} \pm 0.94$ & $9.64^{\mathrm{ab}} \pm 1.07$ & 1.185 \\
\hline $\begin{array}{l}\text { Total } \\
\text { carbohydrate* }\end{array}$ & $47.43^{\mathrm{a}} \pm 1.39$ & $50.64^{\mathrm{a}} \pm 1.99$ & $53.72^{\mathrm{a}} \pm 2.15$ & $51.77^{\mathrm{a}} \pm 1.76$ & $52.88^{\mathrm{a}} \pm 1.65$ & $50.85^{\mathrm{a}} \pm 1.85$ & $43.65^{b} \pm 3.29$ & 3.879 \\
\hline
\end{tabular}

Data are expressed as mean \pm SD. Values given represent means of three determinations.

Means in the same row with different letters are significantly $(P \leq 0.05)$ different.

LSD: least different significantly at $P \leq 0.05$ according to Duncan's multiple range test.

${ }^{*}$ By difference.

Samples $(2 \mathrm{~g})$ were homogenized in $80 \%$ aqueous ethanol at room temperature and centrifuged in cold at $10000 \mathrm{rpm}$ for $15 \mathrm{~min}$ at $4^{\circ} \mathrm{C}$, and the supernatant was preserved. The residue was reextracted twice with $80 \%$ ethanol, and supernatants were pooled and evaporated to dryness at room temperature. Residue was dissolved in $5 \mathrm{~mL}$ of distilled water. One hundred microliter of this extract was diluted to $3 \mathrm{~mL}$ with water and $0.5 \mathrm{~mL}$ of Folin-Ciocalteu reagent was added. After $3 \mathrm{~min}, 2 \mathrm{~mL}$ of $20 \%$ of sodium carbonate was added, and the contents were mixed thoroughly. After standing for $60 \mathrm{~min}$ at room temperature, the absorbance was measured at $650 \mathrm{~nm}$. Phenolic contents were calculated on the basis of the standard curve for gallic acid (GAL). The results were expressed as $\mathrm{mg}$ of gallic acid equivalent per $100 \mathrm{~g}$ DW.

2.3.5. Determination of Total Flavonoids. The total flavonoids content was determined using the Dowd method [14]. $5 \mathrm{~mL}$ of $2 \%$ aluminium trichloride $\left(\mathrm{AlCl}_{3}\right)$ in methanol was mixed with the same volume of the methanolic extract solution $(0.4 \mathrm{mg} / \mathrm{mL})$. After ten minutes the absorbance was measured at $415 \mathrm{~nm}$ using PerkinElmer UV-VIS Lambda.Blank sample consisting of a $5 \mathrm{~mL}$ extract solution with $5 \mathrm{~mL}$ methanol without $\mathrm{AlCl}_{3}$. The total flavonoid content was determined using a standard curve with catechin $(0-100 \mathrm{mg} / \mathrm{L})$ as the standard. Total flavonoids content is expressed as $\mathrm{mg}$ of catechin equivalents (CE)/100 g DW.

\subsubsection{Measurement of Antioxidant Activity by DPPH}

Extraction. Ten $\mathrm{g}(10 \mathrm{~g})$ of raw and processed cauliflower was homogenized with $100 \mathrm{~mL}$ methanol for $1 \mathrm{~min}$ and centrifuged at $10000 \mathrm{rpm}$ for $15 \mathrm{~min}$ at $4^{\circ} \mathrm{C}$. The clear supernatant was transferred to a glass bottle and measured immediately for total antioxidant activity using DPPH assay. $100 \mu \mathrm{L}$ of sample was added to $5 \mathrm{~mL} \mathrm{DPPH}$ solution, and the absorbance of DPPH reagent was determined at $515 \mathrm{~nm}$ after 30 min of incubation [15]. The inhibition percentage of the absorbance was calculated as follows:

$$
\text { Inhibition } \%=\frac{\left(\mathrm{Abs} t_{0}-\mathrm{Abs} t_{30} \mathrm{~min}\right)}{\mathrm{Abs} t_{0} \times 100} .
$$

Abs $t_{0}$ min was the absorbance of DPPH at time 0 . Abs $t_{30}$ min was the absorbance of DPPH after 30 min of incubation.

2.3.7. Analysis of Phenolic Compounds Using HPLC. Phenolic compounds of methanolic extract of raw and processed cauliflower were identified using a method introduced by [16]. Briefly, HPLC analyses were performed using an HP1100 system with a thermostatically controlled column oven and a UV detector was set at $280 \mathrm{~nm}$ (Hewlett-Packard, Palo Alto, CA, USA). Samples and mobile phases were filtrated through a $0.45 \mathrm{~mm}$ Millipore filter, type GV (Millipore, Bedford, MA, USA), prior to HPLC injection. Each sample was analyzed in triplicate. The identified phenolic compounds were quantified on the basis of their peak area and compared with calibration curves obtained with the corresponding standards and then expressed as $\mathrm{mg} / 100 \mathrm{~g}$ of extract.

2.3.8. Statistical Analysis. Data were statistically analyzed in completely randomized design in factorial arrangement, according to the procedures outlined by [17], and the treatments means were compared by least significant differences (LSD) and Duncan' multiple range using SPSS program package.

\section{Results and Discussion}

3.1. Chemical Composition. Chemical compositions of raw, blanched, and cooked cauliflower are presented in Table 1. Blanching and boiling processes caused significant increases in moisture content; percent increments ranged from $1.4 \%$ to $4.33 \%$. This increase in moisture content might be due to leaching of water-soluble nutrients during blanching and boiling processes [18]. The highest $(P<0.05)$ loss of dry matter was observed for water-boiled cauliflower. During boiling, cellulose is little affected, but the middle lamella gets broken down by heat, thus making vegetables to take up water as the starch gelatinizes. The longer the boiling time, therefore, the higher the moisture content [19]. However, stir-fried 
TABLE 2: Effect of different blanching and cooking methods on selected mineral contents of cauliflower florets (mg/100 g dry weight basis).

\begin{tabular}{|c|c|c|c|c|c|c|c|c|c|}
\hline Treat & $\mathrm{Na}$ & K & $\mathrm{Ca}$ & $\mathrm{Mg}$ & $\mathrm{P}$ & S & $\mathrm{Zn}$ & $\mathrm{Mn}$ & $\mathrm{Fe}$ \\
\hline Raw & $92^{\mathrm{a}} \pm 10.25$ & $3657^{\mathrm{a}} \pm 12.02$ & $480^{\mathrm{a}} \pm 8.24$ & $450^{\mathrm{a}} \pm 9.55$ & $329^{\mathrm{a}} \pm 22.51$ & $720^{\mathrm{a}} \pm 9.32$ & $25.3^{\mathrm{a}} \pm 2.01$ & $2.15^{\mathrm{a}} \pm 0.58$ & $26.2^{\mathrm{a}} \pm 1.96$ \\
\hline Steam blanching & $\operatorname{g} 387^{\mathrm{a}} \pm 13.37$ & $3132^{c} \pm 7.42$ & $460^{\mathrm{ab}} \pm 9.67$ & $432^{\mathrm{ab}} \pm 8.24$ & $308^{\mathrm{a}} \pm 31.12$ & $712^{\mathrm{a}} \pm 5.19$ & $24.1^{\mathrm{a}} \pm 3.18$ & $1.95^{\mathrm{a}} \pm 0.08$ & $24.1^{\mathrm{a}} \pm 2.83$ \\
\hline Water blanchi & $\operatorname{g~} 331^{c} \pm 6.34$ & $2998^{\mathrm{d}} \pm 8.17$ & $432^{b c} \pm 5.82$ & $412^{\mathrm{b}} \pm 14.27$ & $304^{\mathrm{a}} \pm 22.01$ & $708^{\mathrm{a}} \pm 7.02$ & $23.5^{\mathrm{a}} \pm 4.01$ & $1.90^{\mathrm{a}} \pm 0.41$ & $22.4^{\mathrm{a}} \pm 1.75$ \\
\hline Ste & $356^{\mathrm{b}} \pm 8.02$ & $3120^{c} \pm 5.37$ & $454^{\mathrm{ab}} \pm 11.30$ & $430^{\mathrm{ab}} \pm 13.29$ & $305^{\mathrm{a}} \pm 20.11$ & $710^{\mathrm{a}} \pm 10.34$ & $24.6^{\mathrm{a}} \pm 1.97$ & $1.93^{\mathrm{a}} \pm 0.37$ & $23.6^{\mathrm{a}} \pm 0.85$ \\
\hline & $309^{\mathrm{d}} \pm 11.78$ & $2754^{\mathrm{e}} \pm 6.59$ & $426^{\mathrm{C}} \pm 7.09$ & $405^{\mathrm{b}} \pm 11.07$ & $298^{a} \pm 6.07$ & $706^{\mathrm{a}} \pm 5.48$ & $23.1^{\mathrm{a}} \pm 2.56$ & $1.87^{\mathrm{a}} \pm 0.12$ & $20.1^{\mathrm{a}} \pm 3.12$ \\
\hline & $384^{a} \pm 9.60$ & $3241^{\mathrm{b}} \pm 13.20$ & $462^{\mathrm{ab}} \pm 22.14$ & $430^{\mathrm{ab}} \pm 13.06$ & $322^{\mathrm{a}} \pm 22.16$ & $720^{a} \pm 6.77$ & $24.2^{\mathrm{a}} \pm 3.54$ & $2.05^{\mathrm{a}} \pm 0.64$ & $24.4^{\mathrm{a}} \pm$ \\
\hline & $385^{\mathrm{a}} \pm 5.23$ & $3238^{\mathrm{b}} \pm 22.36$ & $458^{\mathrm{ab}} \pm 13.56$ & $442^{\mathrm{a}} \pm 10.64$ & $324^{\mathrm{a}} \pm 10.14$ & $718^{\mathrm{a}} \pm 11.25$ & $24.4^{\mathrm{a}} \pm 2.10$ & $2.09^{\mathrm{a}} \pm 0.32$ & $25.1^{\mathrm{a}} \pm 1$ \\
\hline $\mathrm{SD}$ at 0.05 & 16.83 & 20.98 & 21.40 & 20.35 & 36.22 & 14.38 & 5.02 & 0.717 & 4.896 \\
\hline
\end{tabular}

Data are expressed as mean $\pm \mathrm{SD}$. Values given represent means of three determinations.

Means in the same row with different letters are significantly $(P \leq 0.05)$ different.

LSD: least different significantly at $P \leq 0.05$ according to Duncan's multiple range test.

cauliflower had significantly $(P \leq 0.05)$ lower moisture contents than raw, blanched, boiled, and microwaved cauliflowers. During the frying process, water evaporates from inside the product being fried, creating voids that are penetrated by the oil. As long as there is moisture to evaporate, the product will stay at a temperature of roughly $100^{\circ} \mathrm{C}[20]$. As the water evaporates, the crust indicative of fried foods is formed on the exterior of the product. Fresh cauliflower has significantly the higher level of protein $27.77 \%$. Blanching, boiling, microwaving, and stir-frying caused significant reductions in crude protein; these reductions were related to the protein denaturation at high temperature [21] during blanching and cooking processes. It is possible that soluble proteins were lost by leaching to the surrounding water [12]. The highest loss in protein content was observed for stir-fried cauliflower. This reduction was related to the fact that during the high temperature of stir-frying, both protein and soluble sugar participated in Maillard reaction and then resulted in their content decline [12]. The lowest loss was observed for microwaved cauliflower (3.16\%). Studies on the effect of microwaves on the nutritional values of food proteins and amino acid content of peas and potatoes have concluded that microwave treatments do not have any significant effect on proteins [22]. Stir-frying process caused significant increase in fat content by $7.52 \%$ as dry weight basis. The absorption of fat through frying caused an increase of dry matter [23, 24], whereas water boiling and blanching caused significant decrease in fat content; these decreases were related to fat oxidation at high temperature [21] and could also be due to leaching effect [25]. No significant changes in fiber content were observed after blanching, steam boiling, microwaving, and stir-frying treatments of cauliflower. However, significant increase in fiber content was observed after water boiling of cauliflower. This increase may be attributed to the significant loss of dry matter into the boiling water [26]. Some studies have also suggested that heat processing can change the solubility and other physicochemical properties of fiber [27]. However, most studies analyzing crude and dietary fiber reported no significant changes in crude or dietary fiber after canning and freezing [28]. Fresh cauliflower had significantly the highest levels of ash $10.57 \%$. The minerals leached from the cauliflower florets into the water at different rates during blanching, cooking treatments. Blanching, boiling, microwaving and stir-frying treatments significantly $(P \leq$ $0.05)$ decreased the ash contents of cauliflower florets. The highest $(P \leq 0.05)$ reduction in the ash content was observed for water-boiled cauliflower. Souci et al. [29] reported a loss of ash in boiled as compared with raw carrots. These decreases might be attributed to their diffusion into cooking water, while steam treatments (blanching and cooking), stirfrying, and microwaving gave the lowest reduction in the ash content. Losses of minerals during cooking are not caused by destruction but only by leaching into the cooking water [30]. No significant $(P \geq 0.05)$ changes in carbohydrate content were observed after blanching, boiling, and microwaving treatments of cauliflower. However, a significant $(P \leq 0.05)$ decrease in carbohydrate content was observed after stirfrying of cauliflower. This decrease may be attributed to the significant increase of fat content during frying process.

3.2. Minerals. Mineral contents of raw, blanched, and cooked cauliflower are presented in Table 2 . The highest $(P \leq$ $0.05)$ reduction in mineral content was observed for waterboiled cauliflower. The minerals leached from cauliflower florets into the water during water boiling process. However, steam blanching, steam boiling, microwaving, and stir-frying treatments resulted in the greatest retention of all minerals. Steam blanching is usually expected to conserve more soluble nutrients than water blanching [31]. Mineral losses in deep fried foods vary from $1 \%$ in potatoes to $26 \%$ in beef, being significantly lower than in boiled foods of the same type [32]. Boiling leads to high losses while stewing, steaming, microwave cooking, and even pressure steaming cause only small losses [33]. Losses of minerals during cooking are not caused by destruction but only by leaching into the cooking water [34]. Water blanching and boiling resulted in the greatest reduction of potassium $(18.02 \% ; 24.69 \%)$, sodium $(15.57 \% ; 21.17 \%)$, and iron $(14.50 \% ; 23.28 \%)$, respectively. The behavior of minerals during blanching is related to their solubility. Potassium, the most abundant mineral in vegetables, is extremely mobile and is easily lost by leaching during blanching because of its high solubility in water. Calcium and magnesium are generally bound to the plant tissue and are not readily lost by leaching and sometimes can 


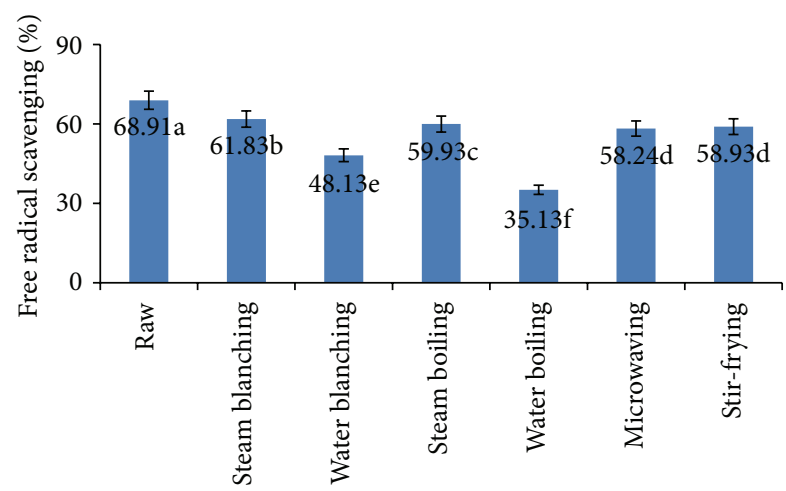

FIGURE 1: Effect of different blanching and cooking methods on vitamin C content. Results represent the means of three experiments.

even be taken up by vegetables during blanching from the processing water in areas with hard water [34].

3.3. Ascorbic Acid. Ascorbic acid is one of the most sensitive vitamins. For this reason, it is often used to evaluate the influences of food processing on vitamin contents [35]. Results in Figure 1 represent the effect of different blanching and cooking methods on ascorbic acid content of cauliflower florets. These results reveal that fresh cauliflower contained the highest level of ascorbic acid $769.23 \mathrm{mg} / 100 \mathrm{~g}$ (on dry weight basis). Blanching and cooking treatments caused significant reductions in ascorbic acid content ranging from $18.86 \%$ to $41.99 \%$. The highest loss was observed for water-blanched and water-boiled cauliflower $38.69 \%$ and $41.99 \%$, respectively. The loss of ascorbic acid can probably be ascribed to water leaching and its thermal degradation, as already reported by Lee and Kader [36]. However, steam-blanched, steam-boiled, microwaved, and stir-fried cauliflower had significantly the highest retention of ascorbic acid content. Boiling leads to high losses in ascorbic acid content levels while stewing, steaming, microwave cooking, and even pressure steaming cause only small losses [33]. Stir-frying resulted in a better retention of ascorbic acid content than cooking with a lot of water or using a microwave [37].

3.4. Total Carotenoids. Carotenoids are plant pigments that are present in human diet as microcomponents of fruits and vegetables [38]. These are a group of aliphatic-alicyclic, fatsoluble, yellow-to-red compounds responsible for red, orange, and yellow color of edible fruits and vegetables and widely distributed in nature [39].

Results in Figure 2 illustrate the effect of different blanching and cooking methods on total carotenoids in cauliflower. These results reveal that fresh cauliflower contained $126.22 \mathrm{mg} / 100 \mathrm{~g}$ carotenoids (on dry weight basis). Water boiling and stir-frying caused significant decreases of total carotenoids, $40.77 \%$ and $39.42 \%$, respectively. Yuan et al. [12] and Vallejo et al. [40] reported that boiling and stir-frying of broccoli resulted in significant decrease in carotenoids. In this respect, Miglio et al. [41] reported that frying of broccoli caused a $67 \%$ loss of the initial carotenoid concentration. This decrease of carotenoids of fried cauliflower may be

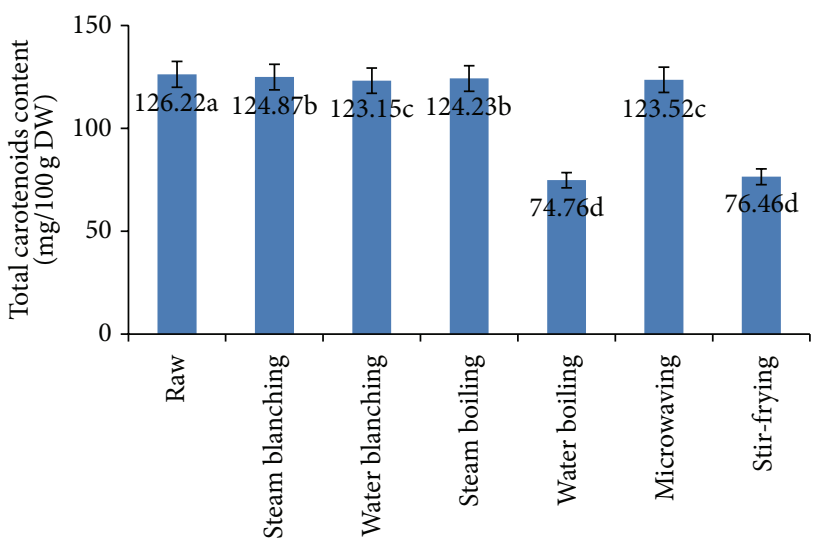

FIGURE 2: Effect of different blanching and cooking methods on total carotenoids content. Results represent the means of three experiments.

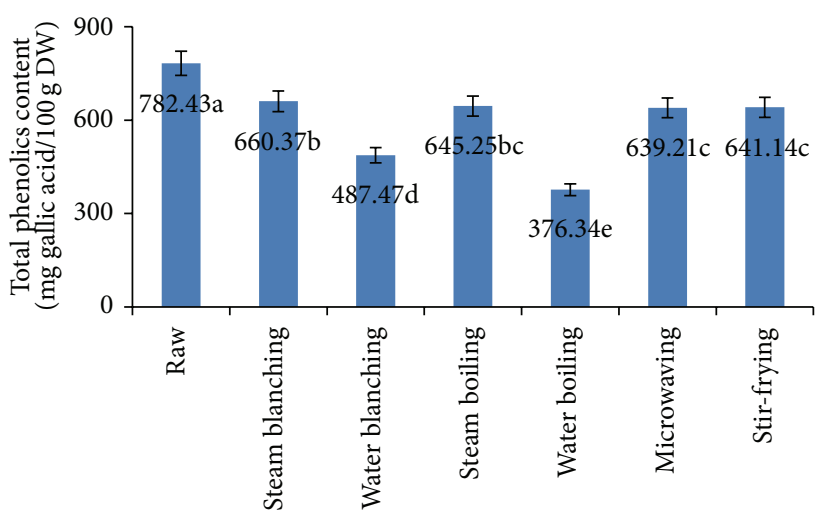

FIGURE 3: Effect of different blanching and cooking methods on total phenolics content. Results represent the means of three experiments.

due to the fact that carotenoids are fat-soluble compounds and readily solubilized during stir-frying and thus resulted in decrease of its contents [42]. On the other hand, there are no significant differences in the content of carotenoids of raw, steam-blanched, water-blanched, steam-boiled and microwaved cauliflower. In general, carotenoid content of foods is not altered to a great extent by common household cooking methods such as microwave cooking, steaming, and boiling, but extreme heat can result in oxidative destruction of carotenoids [43].

3.5. Total Phenolic Compounds. Phenolic compounds (PCs) may contribute directly to the antioxidant action; therefore, it is necessary to investigate total phenolic content. Figure 3 shows the effect of different blanching and cooking methods on total phenolic contents of cauliflower. The initial level of total phenolic in fresh cauliflower was $782.43 \mathrm{mg} / 100 \mathrm{~g}$ (on dry weight basis). Blanching and cooking treatments caused significant losses (15.6\% to $51.9 \%)$ of total phenolic compounds. Phenolic compounds in vegetables are present in both soluble forms and combined with cell-wall complexes. Thus, increased surface area of tissues in contact with cooking 


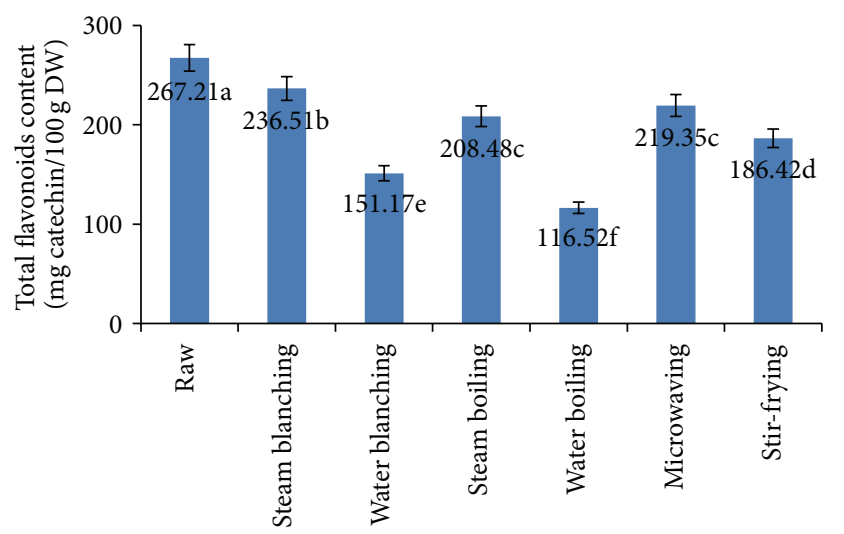

FIGURE 4: Effect of different blanching and cooking methods on total flavonoids content. Results represent the means of three experiments.

water and high cooking temperatures and lengthy cooking times are all likely to have caused disruption of cell walls and breakdown of phenolic compounds [44]. The highest loss was observed for water-boiled and water-blanched cauliflower, $51.90 \%$ and $37.69 \%$, respectively. This could be due to the breakdown of phenolics or losses (leached out) during cooking as most of the bioactive compounds are relatively unstable to heat and easily solubilized [45]. Steam-blanched, steam-boiled, stir-fried, and microwaved cauliflower had significantly the lower losses $16.6 \%, 17.53 \%, 18.05 \%$ and $18.30 \%$, respectively. During steaming, phenolic compounds can remain in the edible part of broccoli, probably owing to the inactivation of oxidative enzymes [40]. Microwaving was better in retention of total phenolics than other cooking methods, while boiling significantly decreased the contents of total phenolics of Boletus mushrooms [46].

3.6. Total Flavonoids. Flavonoids have a wide range of biological activities such as cellproliferation-inhibiting, apoptosis-inducing, enzyme-inhibiting, antibacterial, and antioxidant effects $[47,48]$. Moreover, some findings indicate that flavonoids possess various clinical properties such as antiatherosclerotic, anti-inflammatory, antitumour, antithrombogenic, antiosteoporotic, and antiviral effects $[47,48]$. Figure 4 shows the effect of different blanching and cooking methods on total flavonoids contents of cauliflower. The highest value of total flavonoids was recorded for fresh cauliflower $267.21 \mathrm{mg} / 100 \mathrm{~g}$ (on dry weight basis). Total flavonoids were significantly $(P \leq 0.05)$ decreased by blanching and cooking treatments. The highest reduction was noted after water boiling $(56.39 \%)$ followed by water blanching (43.42\%) and stir-frying (30.23\%). Porter [49] reported that boiling for $5 \mathrm{~min}$ resulted in a $49.55 \%$ reduction in flavonoids in purple-sprouting broccoli. However, steam blanching resulted in the greatest retention of total flavonoids, followed by microwaving and then steam boiling. Conventional boiling led to a significant loss of flavonoids (66\%) from fresh raw broccoli, while high-pressure boiling caused considerable leaching (47\%) of caffeoylquinic acid

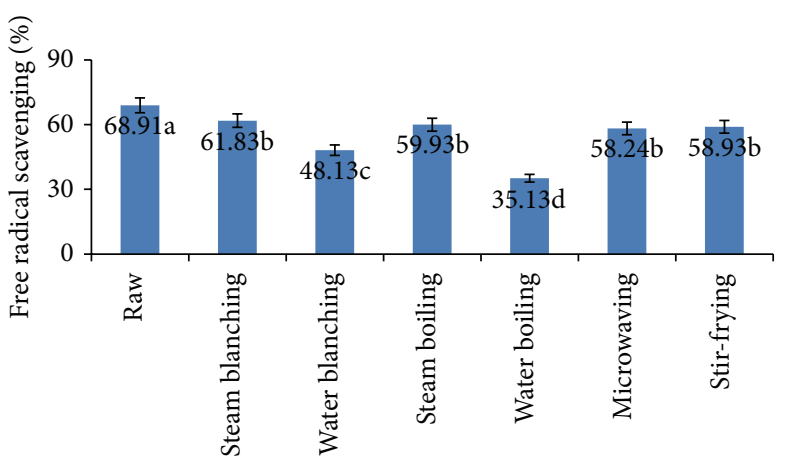

FIGURE 5: Total antioxidant activity of fresh, blanched, and cooked cauliflower. Results represent the means of three experiments.

derivatives into the cooking water. On the other hand, steaming had minimal effects, in terms of loss, on both flavonoid and hydroxycinnamoyl derivative contents [39]. Steam heating at $0.2 \mathrm{MPa}$ during $40 \mathrm{~min}$ induces a decrease of $25 \%$ in flavonoid content of buckwheat [50]. Similar findings were reported with microwaving at $700 \mathrm{~W}$ during $10 \mathrm{~min}$ [50] and $900 \mathrm{~W}$ during $120 \mathrm{~s}$ for barley [51].

3.7. Total Antioxidant Activity. Antioxidant activities of raw and processed cauliflower, as determined by the DPPH radical scavenging method, are shown in Figure 5. In DPPH scavenging assay, the antioxidant activity was measured by the decrease in absorbance as the DPPH radical received an electron or hydrogen radical from an antioxidant compound to become a stable diamagnetic molecule [52]. DPPH radicalscavenging activity expressed in \% inhibition of the raw and processed cauliflower extracts ranged from $35.13 \%$ to $68.91 \%$. Methanolic extract of fresh cauliflower had significantly the highest DPPH radical-scavenging activity (68.91\%) followed by the extracts of steam-blanched, steam-boiled, stir-fried, and microwaved cauliflower, $61.83 \%, 59.15 \%, 58.93 \%$ and $58.24 \%$, respectively. Kenny and O'Beirne [53] indicated that the loss of antioxidant activity was relative to the contact area between vegetables and water as well as processing time. It was clear that the contact areas in steaming and stirfrying processes were much smaller than that in boiling, so their antioxidant substances lost relatively very little [54]. Microwave heating retains the active components in the cooked tissue [55]. The activity of vegetables cooked in the microwave oven was generally higher than that of those cooked in boiling water, because microwave heating, griddling, and baking do not stimulate the release of ascorbic acid or other antioxidants from cooked tissue [56]. However, the extracts of water-boiled and water-blanched cauliflower showed the lowest scavenging activity of $35.13 \%$ and $48.13 \%$, respectively. After boiling process, a lot of the antioxidant substances were running off into the boiling medium, which resulted in decrease of their antioxidant capacities [44]. During vegetable cooking, qualitative changes, antioxidant breakdown, and their leaching into surrounding water may influence the antioxidant activity of the vegetables [57]. 
TABLE 3: HPLC analysis of phenolic compounds (mg/100 g DW) of raw and processed cauliflower.

\begin{tabular}{|c|c|c|c|c|c|c|c|}
\hline Phenolic compounds (mg/100 g) & Raw & Steam blanching & Water blanching & Steam boiling & Water boiling & Microwaving & Stir-frying \\
\hline Gallic & 11.9 & 7.62 & 4.32 & 3.61 & 0.66 & 4.00 & 3.50 \\
\hline Pyrogallol & 18.9 & 13.71 & 6.84 & 11.54 & 4.84 & 14.52 & 12.47 \\
\hline Catechin & 1.91 & 0.85 & ND & 0.71 & ND & ND & ND \\
\hline Protocatechuic & 192.4 & 78.78 & 37.23 & 66.10 & 23.04 & 67.41 & 52.38 \\
\hline Catechol & 4.90 & 0.70 & 0.60 & 0.60 & 0.34 & 0.45 & ND \\
\hline Chlorogenic acid & 25.83 & 11.36 & ND & 8.14 & ND & 12.36 & 10.45 \\
\hline Rosmarinic acid & 1.73 & ND & ND & ND & ND & ND & ND \\
\hline Rutin & 2.57 & 0.24 & 0.01 & 0.01 & ND & 0.12 & ND \\
\hline Caffeic acid & 0.77 & 0.44 & 0.21 & ND & ND & ND & 1.644 \\
\hline Vanillic acid & 11.90 & 0.031 & ND & ND & ND & ND & ND \\
\hline Quercetin & 202.46 & 85.20 & 45.13 & 54.19 & 22.35 & 61.78 & 58.74 \\
\hline Naringenin & 1.81 & ND & ND & ND & ND & ND & ND \\
\hline Syringic acid & 1.91 & ND & ND & ND & ND & ND & ND \\
\hline Coumaric acid & 6.94 & 3.69 & 2.94 & 3.48 & 1.54 & 2.62 & 2.10 \\
\hline Cinnamic acid & 3.10 & 0.35 & ND & 0.25 & 0.24 & ND & ND \\
\hline Kaempferol & 25.91 & 15.12 & 10.91 & 9.21 & 7.34 & 11.36 & 11.84 \\
\hline
\end{tabular}

ND: not detected.

3.8. HPLC Analysis of Phenolic Compounds of Raw, Blanched, and Cooked Cauliflower. HPLC analysis has the advantage over total phenolics content determined by the FolinCiocalteu method, as it provides more precise information of individual compounds. Several polyphenolic compounds were identified in fresh, blanched, and cooked cauliflower. These included gallic, pyrogallol, catechin, protocatechuic acid, catechol, chlorogenic acid, rosmarinic acid, rutin, caffeic acid, vanillic acid, quercetin, naringenin, syringic acid, coumaric acid, cinnamic, and kaempferol (Table 3). These compounds have been identified according to their retention time and the spectral characteristics of their peaks compared to those of standards as well as by spiking the sample with standards. The quantities of the identified compounds are expressed in $\mathrm{mg} / 100 \mathrm{~g}$ DW. The predominant phenolics of raw cauliflower were protocatechuic acid (192.45), quercetin (202.4), pyrogallol (18.9), vanillic acid (11.90), coumaric acid (6.94), and kaempferol (25.91) mg/100 g DW, respectively (Table 3). Water boiling and water blanching showed the most pronounced losses of cauliflower polyphenols (-88.27 and $78.81 \%$, resp.). Phenolic acids are dissolved in vacuoles and apoplast [58]. Cooking of vegetables determines softening and breaking of cellular components with the consequent release of these molecules into the boiling water [59]. The less negative effects on phenolic compounds were observed for steam-blanched, microwaved, steam-boiled, and stir-fried cauliflower $(-57.80 \%, 66.08 \%, 69.34 \%$, and $70.26 \%$, resp.). Steaming and microwaving were better in retention of phenolic compounds than other cooking methods, while boiling significantly decreased the contents of these compounds of broccoli and mushrooms $[40,46]$. During steaming and frying, moreover, the hydrolysis of chlorogenic acid into caffeic and quinic acids may also occur, justifying the significant increases of caffeic acid observed for both cooking methods [41]. It is worthy to mention that polyphenol losses could also be due to the covalent binding between oxidized phenols and proteins or amino acids as well as the polymerization of oxidized phenols [59].

\section{Conclusion}

As shown in this study, blanching, boiling, microwaving, and stir-frying affect the composition, phytochemical contents, antioxidant activity, and phenolic profiles of white cauliflower. Water boiling and blanching processes caused significant losses of dry matter, protein, mineral, and phytochemical contents as well as scavenging of $\mathrm{DPPH}^{\bullet}$ radical. However, steam treatments (blanching and cooking), stirfrying, and microwaving caused slight losses, and they result in the greatest retention of nutrients and phytochemicals.

\section{References}

[1] K. B. Pandey and S. I. Rizvi, "Plant polyphenols as dietary antioxidants in human health and disease," Oxidative Medicine and Cellular Longevity, vol. 2, no. 5, pp. 270-278, 2009.

[2] M. Jahangir, H. K. Kim, Y. H. Choi, and R. Verpoorte, "Healthaffecting compounds in Brassicaceae," Comprehensive Reviews in Food Science and Food Safety, vol. 8, no. 2, pp. 31-43, 2009.

[3] F. Vallejo, F. A. Tomás-Barberán, and C. García-Viguera, "Phenolic compound contents in edible parts of broccoli inflorescences after domestic cooking," Journal of the Science of Food and Agriculture, vol. 83, no. 14, pp. 1511-1516, 2003.

[4] D. Heimler, P. Vignolini, M. G. Dini, F. F. Vincieri, and A. Romani, "Antiradical activity and polyphenol composition of local Brassicaceae edible varieties," Food Chemistry, vol. 99, no. 3, pp. 464-469, 2006.

[5] Y. Zhang and P. Talalay, "Anticarcinogenic activities of organic isothiocyanates: chemistry and mechanisms," Cancer Research, vol. 54, no. 7, supplement, pp. 1976s-1981s, 1994. 
[6] J. N. Boyd, J. G. Babish, and G. S. Stoewsand, "Modification by beet and cabbage diets of aflatoxin B1-induced rat plasma $\alpha$ foetoprotein elevation, hepatic tumorigenesis, and mutagenicity of urine," Food and Chemical Toxicology, vol. 20, no. 1, pp. 47-52, 1982.

[7] C. A. Bradfield, Y. Chang, and L. F. Bjeldanes, "Effects of commonly consumed vegetables on hepatic xenobiotic-metabolizing enzymes in the mouse," Food and Chemical Toxicology, vol. 23, no. 10, pp. 899-904, 1985.

[8] R. Fennema Owen, Food Chemistry, Marcel Dekkar, New York, NY, USA, 3rd edition, 1996.

[9] FAOSTAT, "Database," Agricultural Data, 2004, http://www .fao.org/home/en/.

[10] AOAC, Official Methods of Analysis of the Association of Official Analytical Chemists, Washington, DC, USA, 17th edition, 2000, Edited by: W. Horwitz.

[11] AOAC, "Association of Official Analytical Chemists. Official Method 985. 33. Vitamin C, (Reduced Ascorbic Acid) in Readyto-feed Milk based Infant Formula 2, 6-Dichloroindophenol Titrimetric Method," in Official Methods of Analysis, pp. 11081109, AOAC International, Washington, DC, USA, 1990.

[12] G.-F. Yuan, B. Sun, J. Yuan, and Q.-M. Wang, "Effects of different cooking methods on health-promoting compounds of broccoli," Journal of Zhejiang University B, vol. 10, no. 8, pp. 580588, 2009.

[13] V. L. Singleton and J. J. Rossi, "Colorimetry of total phenolics with phosphomolybdic-phosphotungstic acid reagents," American Journal of Enology and Viticulture, vol. 16, pp. 144-158, 1965.

[14] A. Meda, C. E. Lamien, M. Romito, J. Millogo, and O. G. Nacoulma, "Determination of the total phenolic, flavonoid and proline contents in Burkina Fasan honey, as well as their radical scavenging activity," Food Chemistry, vol. 91, no. 3, pp. 571-577, 2005.

[15] W. Brand-Williams, M. E. Cuvelier, and C. Berset, "Use of a free radical method to evaluate antioxidant activity," LWT-Food Science and Technology, vol. 28, no. 1, pp. 25-30, 1995.

[16] J.-W. Wu, C.-L. Hsieh, H.-Y. Wang, and H.-Y. Chen, "Inhibitory effects of guava (Psidium guajava L.) leaf extracts and its active compounds on the glycation process of protein," Food Chemistry, vol. 113, no. 1, pp. 78-84, 2009.

[17] K. A. Gomez and A. A. Gomez, Statistical Procedures for Agricultural 446 Research, John Wiley \& Sons, New York, NY, USA, 1984.

[18] J. C. Rickman, D. M. Barrett, and C. M. Bruhn, "Nutritional comparison of fresh, frozen and canned fruits and vegetables. Part 1. Vitamins C and B and phenolic compounds," Journal of the Science of Food and Agriculture, vol. 87, no. 6, pp. 930-944, 2007.

[19] H. G. Muller, An Introduction to Tropical Food Science, Cambridge University Press, New York, NY, USA, 1988.

[20] M. M. Blumenthal, "Frying technology," in Bailey's Industrial Oil and Fat Products, Y. H. Hui, Ed., vol. 3 of Edible Oil and Fat Products: Products and Application Technology, John Wiley \& Sons, New York, NY, USA, 5th edition, 1996.

[21] C. K. Sahni, D. S. Khurdiya, M. A. Dalal, and S. B. Maini, "Microwave processing of foods-potential and prospects," Indian Food Packer, vol. 5, pp. 32-41, 1997.

[22] E. Torringa, E. Esveld, I. Scheewe, R. Van den Berg, and P. Bartels, "Osmotic dehydration as a pre-treatment before combined microwave-hot-air drying of mushrooms," Journal of Food Engineering, vol. 49, no. 2-3, pp. 185-191, 2001.
[23] M. Ghelichpour and B. Shabanpour, "The investigation of proximate composition and protein solubility in processed mullet fillets," International Food Research Journal, vol. 18, no. 4, pp. 1343-1347, 2011.

[24] N. Gokoglu, P. Yerlikaya, and E. Cengiz, "Effects of cooking methods on the proximate composition and mineral contents of rainbow trout (Oncorhynchus mykiss)," Food Chemistry, vol. 84, no. 1, pp. 19-22, 2004.

[25] D. I. Gernah, B. M. Ega, and U. E. Umoh, "Effect of boiling time on the quality of "Zogale": a snack food produced from peanut (Arachis hypogea) cake and boiled Moringa oleifera leaves," African Journal of Food Science, vol. 6, no. 10, pp. 287-293, 2012.

[26] E. M. G.-L. Nyman and S. J. M. Svanberg, "Modification of physicochemical properties of dietary fibre in carrots by monoand divalent cations," Food Chemistry, vol. 76, no. 3, pp. 273280, 2002.

[27] J. Fava, S. M. Alzamora, and M. A. Castro, "Structure and nanostructure of the outer tangential epidermal cell wall in vaccinium corymbosum L. (Blueberry) fruits by blanching, freezing-thawing and ultrasound," Food Science and Technology International, vol. 12, no. 3, pp. 241-251, 2006.

[28] J. C. Rickman, C. M. Bruhn, and D. M. Barrett, "Nutritional comparison of fresh, frozen, and canned fruits and vegetables II. Vitamin A and carotenoids, vitamin E, minerals and fiber," Journal of the Science of Food and Agriculture, vol. 87, no. 7, pp. 1185-1196, 2007.

[29] S. W. Souci, W. Fachmann, and H. Kraut, Food Composition and Nutrition Tables, CRC Press, Medpharm Scientific Publishers, New York, NY, USA, 5th edition, 1994.

[30] D. Miller, "Minerals," in Food Chemistry, O. R. Fennema, Ed., Marcel Dekker, New York, NY, USA, 3rd edition, 1996.

[31] D. Odland and M. S. Eheart, "Ascorbic acid, mineral and quality retention in frozen broccoli blanched in water, steam and amonia stream," Journal of Food Science, vol. 40, pp. 10041007, 1975.

[32] A. Bognár, "Comparative study of frying to other cooking techniques influence on the nutritive value," Grasas y Aceites, vol. 49, no. 4-5, pp. 250-260, 1998.

[33] S. Loh, Bewertung des Einflusses Verschiedener Garverfahren auf die Sensorische und Ernahrungsphysiologische Qualita t von Frischen und TK-Gemusen Anhand Ausgewahlter Parameter, Cuvillier, Gottingen, Germany, 2004.

[34] R. Puupponen-Pimiä, S. T. Häkkinen, M. Aarni et al., "Blanching and long-term freezing affect various bioactive compounds of vegetables in different ways," Journal of the Science of Food and Agriculture, vol. 83, no. 14, pp. 1389-1402, 2003.

[35] A. Bognár, "Untersuchungen uber den Einfluss der Temperaturund Verpackung auf den Genuss- und Nahrwert von frischemGem se und Obst bei der Lagerung Kuhlschrank," Ernahrungs-Umschau, vol. 36, pp. 254-263, 1989.

[36] S. K. Lee and A. A. Kader, "Preharvest and postharvest factors influencing vitamin C content of horticultural crops," Postharvest Biology and Technology, vol. 20, no. 3, pp. 207-220, 2000.

[37] L. Fillion and C. J. K. Henry, "Nutrient losses and gains during frying: a review," International Journal of Food Sciences and Nutrition, vol. 49, no. 2, pp. 157-168, 1998.

[38] S. Ranganne, Plant Pigments, McGraw Hill, New Delhi, India, 1977.

[39] J. C. Bauernfeind, Carotenoids as Colorants and Vitamin A Precursors, Academic Press, New York, NY, USA, 1981. 
[40] F. Vallejo, F. A. Tomás-Barberán, and C. Garcia-Viguera, "Glucosinolates and vitamin $\mathrm{C}$ content in edible parts of broccoli florets after domestic cooking," European Food Research and Technology, vol. 215, no. 4, pp. 310-316, 2002.

[41] C. Miglio, E. Chiavaro, A. Visconti, V. Fogliano, and N. Pellegrini, "Effects of different cooking methods on nutritional and physicochemical characteristics of selected vegetables," Journal of Agricultural and Food Chemistry, vol. 56, no. 1, pp. 139-147, 2008.

[42] A. H. Azizah, K. C. Wee, A. Osman, and A. Misran, "Effect of boiling and stir frying on total phenolics, carotenoids and radical scavenging activity of pumpkin (Cucurbita moschato)," International Food Research Journal, vol. 16, no. 1, pp. 45-51, 2009.

[43] C. Thane and S. Reddy, "Processing of fruits and vegetables: effect on carotenoids," Nutrition \& Food Science, vol. 2, pp. 5865, 1997.

[44] M. Francisco, P. Velasco, D. A. Moreno, C. García-Viguera, and M. E. Cartea, "Cooking methods of Brassica rapa affect the preservation of glucosinolates, phenolics and vitamin C," Food Research International, vol. 43, no. 5, pp. 1455-1463, 2010.

[45] D. Zhang and Y. Hamauzu, "Phenolics, ascorbic acid, carotenoids and antioxidant activity of broccoli and their changes during conventional and microwave cooking," Food Chemistry, vol. 88, no. 4, pp. 503-509, 2004.

[46] L. Sun, X. Bai, and Y. Zhuang, "Effect of different cooking methods on total phenolic contents and antioxidant activities of four Boletus mushrooms," Journal of Food Science and Technology, 2012.

[47] N. C. Cook and S. Samman, "Flavonoids-Chemistry, metabolism, cardioprotective effects, and dietary sources," Journal of Nutritional Biochemistry, vol. 7, no. 2, pp. 66-76, 1996.

[48] B. H. Havsteen, "The biochemistry and medical significance of the flavonoids," Pharmacology and Therapeutics, vol. 96, no. 2-3, pp. 67-202, 2002.

[49] Y. Porter, "Antioxidant properties of green broccoli and purplesprouting broccoli under different cooking conditions," Bioscience Horizons, vol. 5, pp. 1-11, 2012.

[50] M. Zhang, H. Chen, J. Li, Y. Pei, and Y. Liang, "Antioxidant properties of tartary buckwheat extracts as affected by different thermal processing methods," LWT-Food Science and Technology, vol. 43, no. 1, pp. 181-185, 2010.

[51] P. Sharma and H. S. Gujral, "Effect of sand roasting and microwave cooking on antioxidant activity of barley," Food Research International, vol. 44, no. 1, pp. 235-240, 2011.

[52] T. Juntachote and E. Berghofer, "Antioxidative properties and stability of ethanolic extracts of Holy basil and Galangal," Food Chemistry, vol. 92, no. 2, pp. 193-202, 2005.

[53] O. Kenny and D. O'Beirne, "The effects of washing treatment on antioxidant retention in ready-to-use iceberg lettuce," International Journal of Food Science and Technology, vol. 44, no. 6, pp. 1146-1156, 2009.

[54] J.-J. Zhang, R. Ji, Y.-Q. Hu, J.-C. Chen, and X.-Q. Ye, "Effect of three cooking methods on nutrient components and antioxidant capacities of bamboo shoot (Phyllostachys praecox C.D. Chu et C.S. Chao)," Journal of Zhejiang University B, vol. 12, no. 9, pp. 752-759, 2011.

[55] T. Yamaguchi, T. Mizobuchi, R. Kajikawa et al., "Radicalscavenging activity of vegetables and the effect of cooking on their activity," Food Science and Technology Research, vol. 7, no. 3, pp. 250-257, 2001.
[56] A. M. Jiménez-Monreal, L. García-Diz, M. Martínez-Tomé, M. Mariscal, and M. A. Murcia, "Influence of cooking methods on antioxidant activity of vegetables," Journal of Food Science, vol. 74, no. 3, pp. H97-H103, 2009.

[57] A. Podsedek, "Natural antioxidants and antioxidant capacity of Brassica vegetables: a review," LWT-Food Science and Technology, vol. 40, no. 1, pp. 1-11, 2007.

[58] W. Kalt, "Effects of production and processing factors on major fruit and vegetable antioxidants," Journal of Food Science, vol. 70, no. 1, pp. R11-R19, 2005.

[59] M. Friedman, "Food browning and its prevention: an overview," Journal of Agricultural and Food Chemistry, vol. 44, no. 3, pp. 631-653, 1996. 

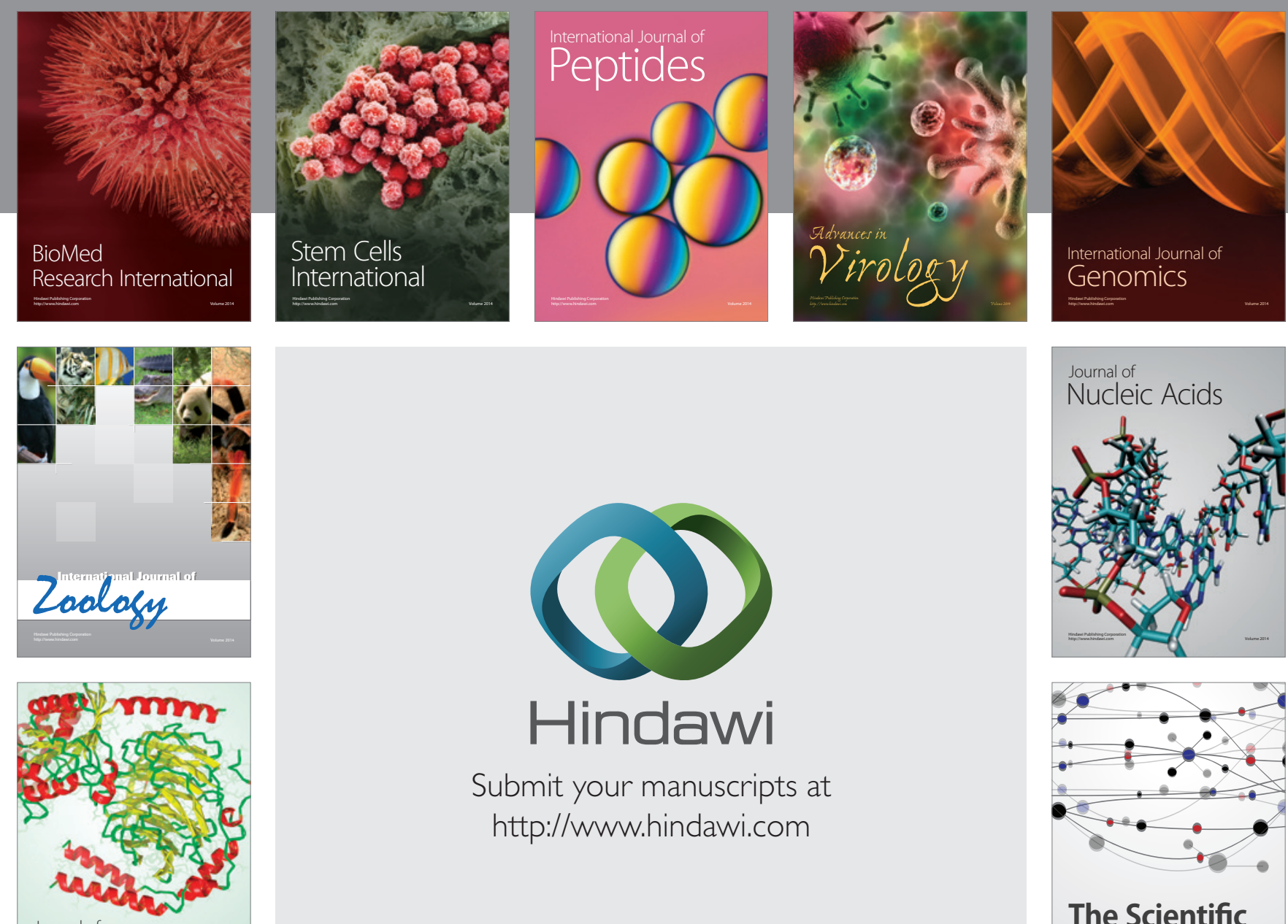

Submit your manuscripts at

http://www.hindawi.com

Journal of
Signal Transduction
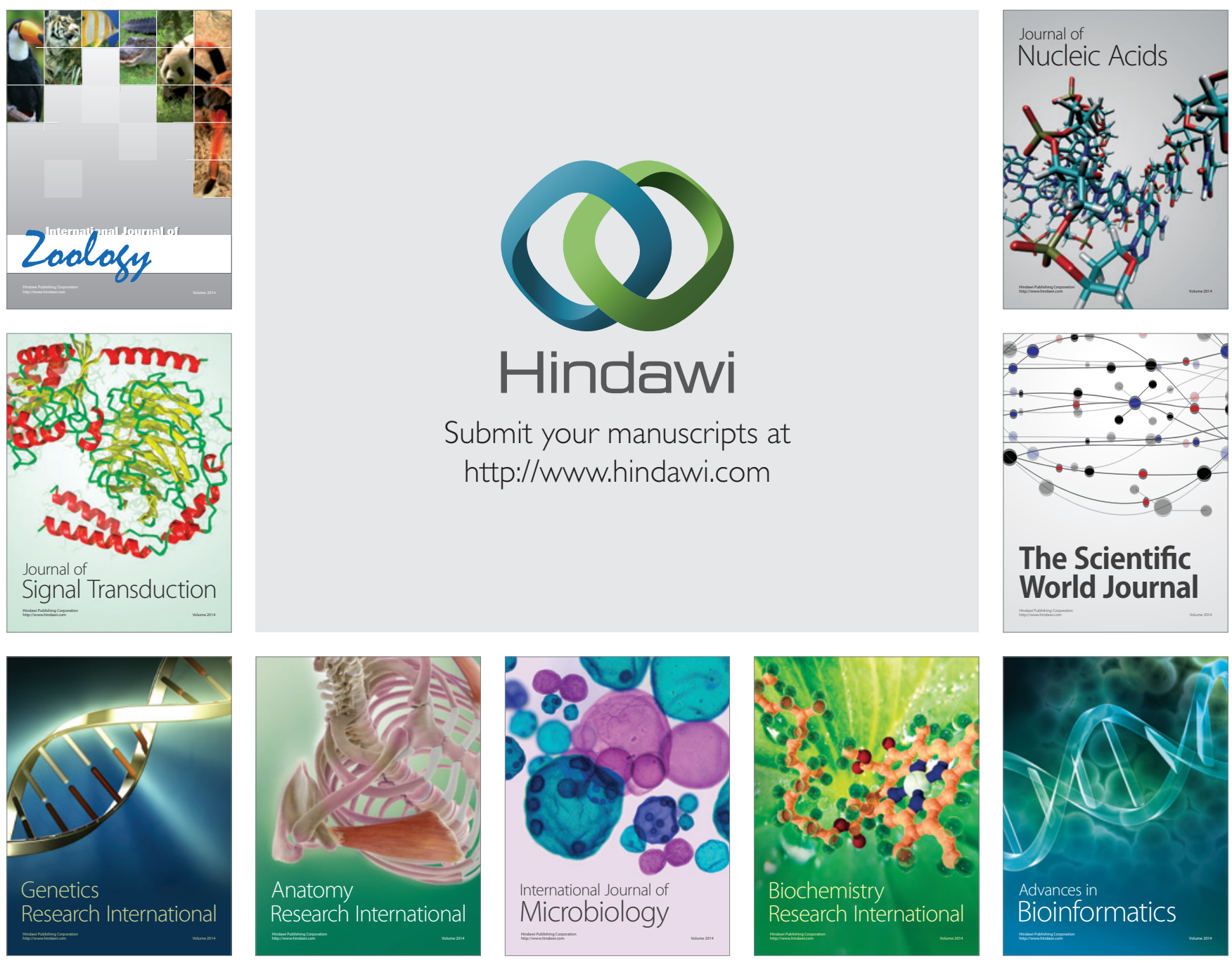

The Scientific World Journal
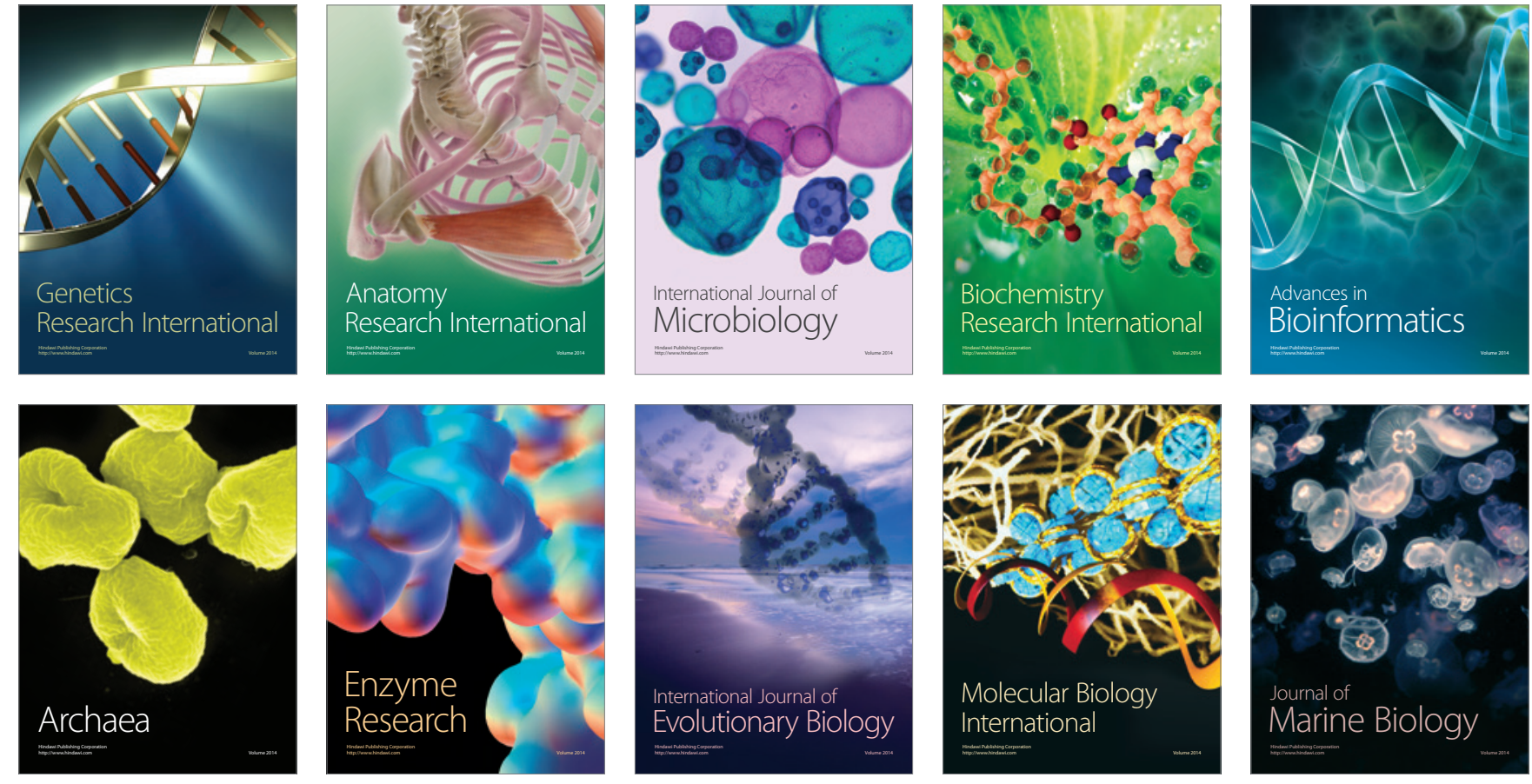